\title{
Determinants of axial osmotic gradients in the differentiating countercurrent system
}

\author{
MICHAEL F. HORSTER, ALBERT GILG, AND PETER LORY \\ Physiologisches Institut der Universität München, and Mathematisches Institut \\ der Technischen Universität München, D-8000 München 2, Federal Republic of Germany
}

Horster, Michael F., Albert Gilg, and Peter Lory. Determinants of axial osmotic gradients in the differentiating countercurrent system. Am. J. Physiol. 246 (Renal Fluid Electrolyte Physiol. 15): F124-F132, 1984.-The renal medullary countercurrent system differentiates into its final segmental nephron function and geometry during perinatal development. The influence of these changes on the medullary longitudinal osmotic gradient cannot be evaluated by experimental studies. Therefore, a computation analysis using a differential equation model of the renal countercurrent system was applied to quantitate the effect of medullary architecture and solute transport on the concentration profiles for salt and urea in tubules (loop of Henle and collecting duct) and in the central core along the entire medulla during ontogeny. The results indicate that both the changing distribution of loop segments within the medulla and the increase in active salt transport of the individual thick ascending loop determine the magnitude and slope of the axial medullary solute gradients.

renal medullary ontogeny; mathematical model; medullary geometry; active salt transport

THE ONTOGENY OF THE renal countercurrent system presents a unique problem because changes of thermodynamic parameters $(9,18,22)$ occur during the postnatal period while the final arrangement of tubules within the medullary microarchitecture is attained ( 9 , $41,42)$. Some of these processes have been measured at the level of the single nephron segment and by tissue slice analysis $(9,11,16,21,46,53)$.

However, no attempts have been made to relate, in a quantitative way, geometry and transport processes in the medulla to the changing longitudinal osmotic gradients $(9,21,58)$ within the countercurrent system. Specifically, loops of Henle from the outer cortical and midcortical layers appear by elongation in the outer medulla $(9,42,43,51)$ within a short period (rat) while the salt transport capacity of the individual loop segment increases $(17,59)$. These parameters have been studied, for technical reasons, in different species. The present model analysis, which is based on a differential equation model of the renal countercurrent system (35), incorporates structural changes of the rat kidney and thermodynamic parameters, as measured directly, of rabbit nephron segments. Medullary geometry and transport show the same developmental pattern in both species.

F124

\section{METHODS}

\section{Model Parameters}

Developmental stages. According to anatomical studies renal development may be subdivided into several phases $(9,41,43,51)$. Phases in the rat kidney (51) are early (days 1-5), intermediate (days 5-10), and late development (days 10-20). The present model study has defined the initial points of each phase as stages I, II, III, and the final point (day 20) as stage IV, corresponding to the base case of a previous model simulation analysis (35).

\section{Morphological Parameters}

Medullary zones. The total length of the medulla increases by a factor of 2 , from 5 to $10 \mathrm{~mm}$, during development from stage I to IV. The length of the outer medulla $(\mathrm{OM})$ is constant; the inner medulla (IM) increases as shown in Table 1 . Within the outer medulla, the outer stripe (OS) and inner stripe (IS) are expressed only in stages III and IV $(42,43,51)$.

\section{Medullary Architecture}

Distribution and number of medullary tubules. In the final stage, stage IV, short loops all turn in the lower third of the inner stripe (31). Only $30 \%$ of all loops of Henle (LH) reach the inner medulla (32), and it was assumed that about one-sixtieth of all loops turn at the tip of the papilla (38).

Figure 1 shows the change with development of the number of loops present at different medullary levels $(9$, $14,15,41,43,51,52)$. It is apparent that the largest increase (fourfold) in the number of loops within the outer medulla occurs in stages II and III, whereas significant changes within the inner medulla take place up to stage II. From then on, the number of loops at the papillary tip is constant $(9,41,51)$. The number of loops of Henle and vasa recta in stages $I$ and II is equal (51); the increase of vasa recta is small up to stage III, whereas the major change occurs during the late phase of medullary development (43). The number of vasa recta at each medullary level in stage IV is higher by about $30 \%$ than the number of loops (31).

The collecting ducts do not merge in the outer medulla. Within the inner medulla, however, the number of collecting ducts (NCD) is reduced to 10 terminal ducts after 
TABLE 1. Developmental changes of medullary length

\begin{tabular}{lcccc}
\hline & \multicolumn{4}{c}{ Stage } \\
\cline { 2 - 5 } & I & II & III & IV \\
\hline Medulla & 5.0 & 6.5 & 8.0 & 10.0 \\
OM & 4.0 & 4.0 & 4.0 & 4.0 \\
OS & & & 1.5 & 1.5 \\
IS & & & 2.5 & 2.5 \\
IM & 1.0 & 2.5 & 4.0 & 6.0 \\
\hline
\end{tabular}

Length of medulla and the medullary zones at developmental stages I-IV is in millimeters. Data adapted from Ref. 42.
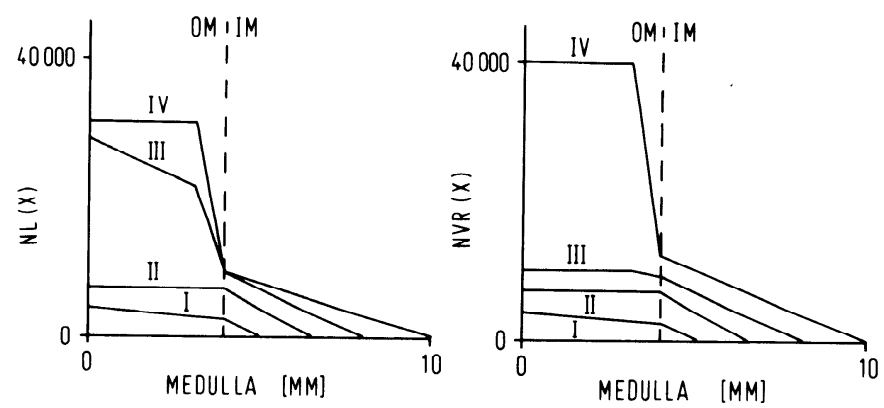

FIG. 1. Number of loops of Henle [NL $(x)]$ and vasa recta [NVR $(x)]$ at different medullary levels $(\mathrm{mm})$ during the 4 stages (I-IV) of renal development.

about nine dichotomous junctions (40). Since six nephrons drain into one collecting duct, the total number of nephrons at the final stage is 30,720 (25), in accordance with direct measurements (40). It should be emphasized that the microarchitecture of the collecting tubule system has already reached its final form in stage I, whereas the radii of collecting tubules continue to change.

Radii of medullary tubules. During development, the radii of the loop of Henle, the distal tubule, the collecting tubule, and vasa recta do not behave in a homogeneous fashion.

Table 2 lists the values $(\mu \mathrm{m})$ for the pertinent tubules. The radii of the loop of Henle (DLH, ALH) and distal convoluted tubule (DCT) do not increase linearly $(2,59)$. The factorial change, calculated from the data and setting the final stage IV to the value 1.0 is as follows: stage I: 0.45 ; stage II: 0.68 ; stage III: 0.82 . The radii of collecting tubules increase linearly but to a smaller extent (59). The lumen of the vasa recta is constant $(43,51,59)$.

For the connecting tubules (CNT), a linear decrease of the radius from the distal tubule to its end was assumed. The length of the distal tubule increases in parallel to that of the total medulla. In the base case, DCT length is $1.0 \mathrm{~mm}$ and CNT length is $2.5 \mathrm{~mm} \mathrm{(26).}$

\section{Intracortical Nephrons}

The present model has incorporated those nephrons that turn their loop within the cortex and deliver their tubular fluid into the medullary collecting duct system. The total number of medullary and cortical nephrons are: stage I: 15,360 ; stage II: 25,600; stage III: 30,720 ; stage IV: 30,720 .
TABLE 2. Developmental changes of medullary tubule radii

\begin{tabular}{lcccr}
\hline \hline & \multicolumn{5}{c}{ Stage } \\
\cline { 2 - 5 } & I & II & III & \multicolumn{1}{c}{ IV } \\
\hline DLH & 3.60 & 5.44 & 6.56 & 8.0 \\
ALH & 4.50 & 6.80 & 8.20 & 10.0 \\
DCT & 4.50 & 6.80 & 8.20 & 10.0 \\
CNT & 3.60 & 5.44 & 6.56 & 8.0 \\
CD & 9.60 & 10.20 & 10.80 & 12.0 \\
DVR & 11.0 & 11.0 & 11.0 & 11.0 \\
AVR & 20.0 & 20.0 & 20.0 & 20.0 \\
\hline
\end{tabular}

Tubular and vascular radii $(\mu \mathrm{m})$ of medullary structures during development (stages I-IV). See METHODS for sources of data. *Values at the end of CNT.

\section{Interstitial Geometry}

The interstitial cross-sectional area in stage IV (final), including the cell volume, has been estimated to be $40 \%$ of the total tubular luminal cross-sectional area (27a, 38 ). Figure 2 depicts the quantitative changes of this parameter with medullary development (stages I-IV). The interstitial cross-sectional area within the inner medulla is constant in stages II-IV. In the outer medulla, a part of the interstitium (BZ, Bindegewebszwickel) (43) decreases in size from stage II to IV while being replaced by tubules entering the interstitium.

\section{Pelvic Geometry}

In the final phase, the last $2 \mathrm{~mm}$ of the papilla reach into the pelvic fluid. The same geometry pertains to stage III, whereas papillary length in the renal pelvis is somewhat smaller in stage I $(1.83 \mathrm{~mm})$ and II $(1.90 \mathrm{~mm})$.

\section{Thermodynamic Parameters}

In contrast to changes within the medullary microarchitecture, only a few of the pertinent thermodynamic parameters have thus far been studied during medullary development. Therefore, values representing the final stage (Table 3), which were measured directly and discussed in a previous study (35), were incorporated into the present study with two exceptions. First, water conductivity $\left(\mathrm{L}_{\mathrm{p}}, \mathrm{ADH}\right)$ increases with development (Table 4 ) in the collecting duct (20). Second, active transport of salt in the thick part of the ascending limb of Henle's loop (TALH), which occurs in the outer but not in the inner medullary segment, is lower at stage I by a factor of 5.8 when compared with the final stage (19). This factorial change was also assumed for the DCT and CNT. Active transport parameters, $V_{\mathrm{m}}$ and $K_{\mathrm{m}}$, are $22 \times 10^{-6}$ $\mathrm{mmol} \cdot \mathrm{cm}^{-2} \cdot \mathrm{s}^{-1}$ and $50 \mathrm{mM}$, respectively, in the final stage. Values of $V_{\mathrm{m}}$ for stages II and III are $16 \times 10^{-6}$ and $19 \times 10^{-6} \mathrm{mmol} \cdot \mathrm{cm}^{-2} \cdot \mathrm{s}^{-1}$, respectively. The plasma concentrations of salt and urea were assumed to be 140 and $9 \mathrm{mM}$, respectively. Tubular fluid concentrations in the DLH were $140 \mathrm{mM}$ for salt and $18 \mathrm{mM}$ for urea at the corticomedullary junction. The volume flow rate at the entry into the countercurrent system is $10 \mathrm{nl} / \mathrm{min}$ and it is lower during the previous phases of develop- 

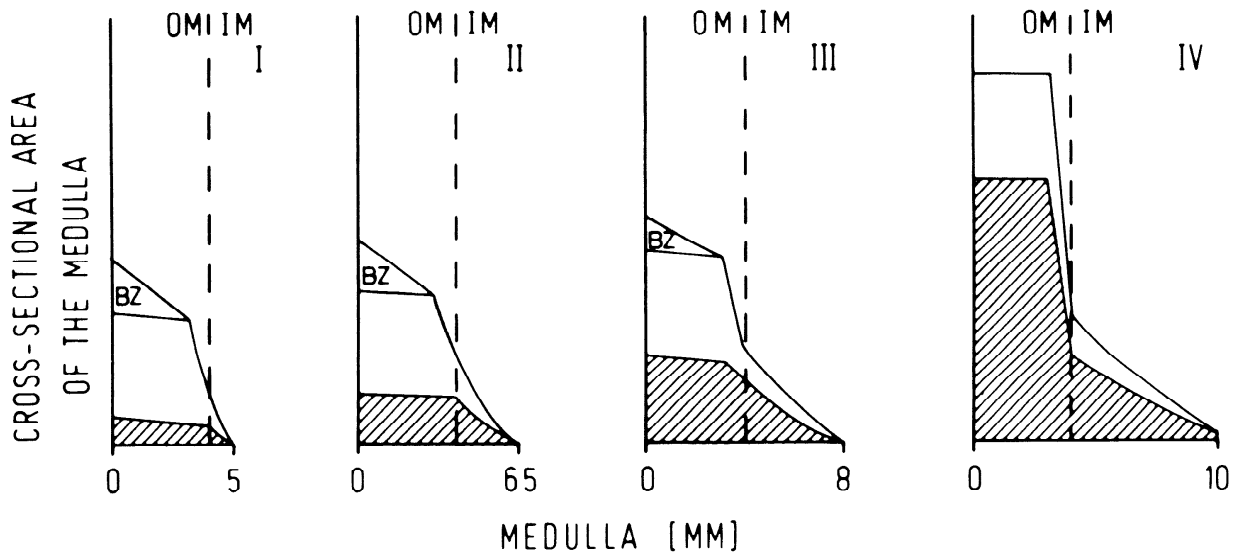

FIG. 2. Total cross-sectional area of medulla from corticomedullary junction (O) to tip of papilla at four stages (I-IV). Hatched area is tubular cross-sectional area. BZ, Bindegewebszwickel.

TABLE 3. Thermodynamic parameters of medullary tubule segments and renal pelvis

\begin{tabular}{|c|c|c|c|c|c|c|c|}
\hline & $\mathrm{DLH}^{*}$ & tALH & TALH/DCT & CNT & OMCD & IMCD & Pelvis \\
\hline $\begin{array}{l}\mathrm{L}_{\mathrm{p}}, \mathrm{nl} \cdot \mathrm{cm}^{-2} \cdot \mathrm{min}^{-1} . \\
\mathrm{mosM}^{-1}\end{array}$ & $\begin{array}{l}247 \\
(28)\end{array}$ & $\begin{array}{l}0 \\
(23)\end{array}$ & $\begin{array}{l}0 \\
(44)\end{array}$ & $\begin{array}{l}\text { lin. } \\
\text { trans.* }\end{array}$ & $\begin{array}{l}48.4 \\
(1)\end{array}$ & $\begin{array}{l}7.37 \\
(45)\end{array}$ & $\begin{array}{l}0 \\
\text { (see Ref. 35) }\end{array}$ \\
\hline $\mathrm{P}_{\mathrm{salt}}, 10^{-5} \mathrm{~cm} / \mathrm{s}$ & $\begin{array}{l}1.61 \\
(28)\end{array}$ & $\begin{array}{l}25 \\
(23)\end{array}$ & $\begin{array}{l}6.27 \\
(44)\end{array}$ & 6.27 & 0 & $\begin{array}{l}0 \\
\text { (see Ref. 35) }\end{array}$ & 0 \\
\hline $\mathrm{P}_{\text {urea }}, 10^{-5} \mathrm{~cm} / \mathrm{s}$ & $\begin{array}{l}1.5 \\
(29)\end{array}$ & $\begin{array}{l}6.7 \\
(23)\end{array}$ & $\begin{array}{l}0 \\
(45)\end{array}$ & lin. & $\begin{array}{l}0.097 \\
(6)\end{array}$ & $\begin{array}{l}2.4 \\
(45)\end{array}$ & $\begin{array}{l}30 \\
\text { (see Ref. 35) }\end{array}$ \\
\hline$\sigma_{\text {salt }}$ & $\begin{array}{l}0.96 \\
(28)\end{array}$ & & & $\begin{array}{l}0.5 \\
(57)\end{array}$ & $\begin{array}{l}1 \\
\text { (see Ref. 35) }\end{array}$ & 1 & 1 \\
\hline$\sigma_{\text {urea }}$ & $\begin{array}{l}0.95 \\
(29)\end{array}$ & & & $\begin{array}{l}0.7 \\
(57)\end{array}$ & $\begin{array}{l}1 \\
(47)\end{array}$ & $\begin{array}{l}0.74 \\
(45)\end{array}$ & 1 \\
\hline
\end{tabular}

Abbreviations are listed in Table 5. Numbers in parentheses indicate references.

Ref. 33). † Linear transition from 0.0 to 1.0 (consistent with Refs. 7 and 57).

TABLE 4. Developmental changes of $L_{p}$ in the $C T$

\begin{tabular}{cccc}
\hline & \multicolumn{3}{c}{ Stage } \\
\cline { 2 - 4 } & I & II & III \\
\hline Outer medulla & 12.97 & 32.04 & 48.4 \\
Inner medulla & 1.92 & 4.74 & 7.37 \\
\hline Water conductivity of the collecting tubule, $\mathrm{nl} \cdot \mathrm{cm}^{-2} \cdot \mathrm{mosM}^{-1} \cdot \mathrm{min}^{-1}$.
\end{tabular}

ment, assuming that single nephron glomerular filtration rate increases linearly $(16,59)$ with the length of the loops of Henle. The concentrations of salt and urea in cortical nephrons at the inflow into the collecting ducts are equal to the plasma concentrations, and volume flow rates $\left(\mathrm{Q}_{\mathrm{CN}}\right)$ were adapted according to the changes in volume absorption in the proximal convoluted tubule (20).

\section{Mathematical Model}

A description of the mathematical model for stage IV (final stage of development; base case) was presented previously (35). Similar to previous models of the renal countercurrent system $(12,37 \mathrm{a}, 38,55,55 \mathrm{a})$, renal function is described by an extensive system of simultaneous differential equations. The abbreviations and symbols used in the present study are given in Table 5 . The differential equations are given in the APPENDIX. They express the changes in solute and water flows that result from transepithelial mass transport and are based on conservation of salt, urea, and water.

In the model, only salt is transported actively and this transport occurs in the TALH and the DCT/CNT only. Hence, the model is based on the passive hypothesis of inner medullary countercurrent multiplication $(30,54)$.

\section{Central Core}

As previously suggested (54), the highly permeable vasa recta (VR) can be functionally merged with the interstitium into a single fluid-filled space called the central core. It must be mentioned, therefore, that the model represents the cross-sectional area of the VR, whereas possible determinants such as incomplete osmotic equilibration between ascending and descending VR, or VR flow rates have not been incorporated. The consequences of the central core assumption for the mathematical modeling of the countercurrent system have been described in detail previously (24).

\section{Loop Architecture}

The loops of Henle turn at different levels of the renal medulla. This loop anatomy was described in the model by the function NL $(x)$ shown in Fig. 1. Because of the large number of nephrons (some 30,000 in the rat kidney), it is not feasible to model each of the loops individ- 
TABLE 5. Abbreviations and symbols

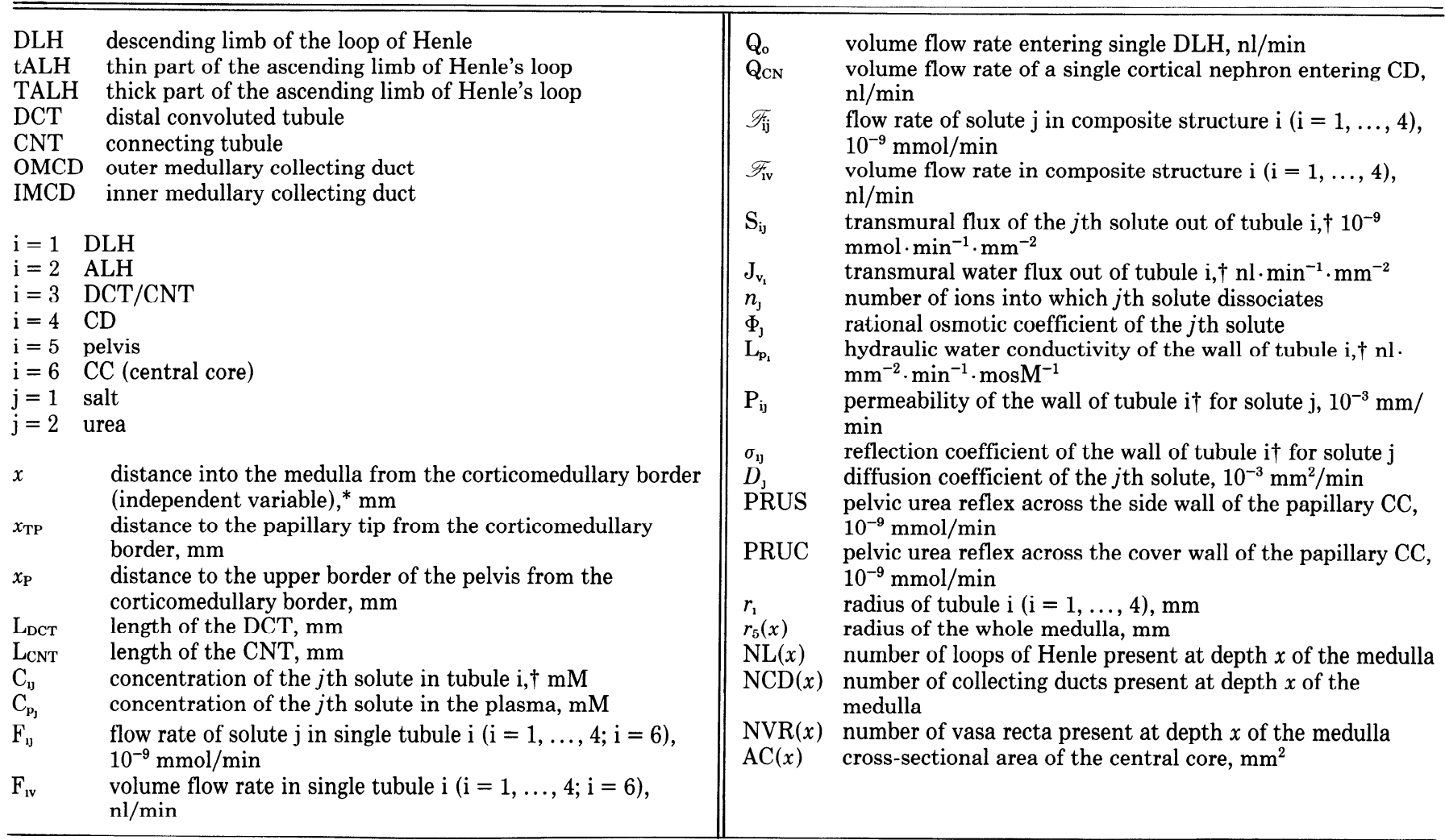

${ }^{*}$ For $\mathrm{i}=3(\mathrm{DCT} / \mathrm{CNT}) x$ is measured along the tubule so that $x=0$ and $x=\mathrm{L}_{\mathrm{DCT}}+\mathrm{L}_{\mathrm{CNT}}$ correspond to its junctions with tubules 2 and 4 , respectively. $\dagger$ For $\mathrm{i}=5$, pelvis.

ually as this would require thousands of basically similar differential equations. In agreement with an earlier suggestion (38), a composite loop structure was applied in the model that has been previously described (35). The flows in the composite loop structure represent the sum of flows in the single loops at the corresponding medullary level, and the concentration of the fluid within the composite structure reflects the mixture of fluids in single tubules.

\section{Collecting Duct Architecture}

According to Kaissling and Kriz (27) and Kriz (31), six nephrons drain into one cortical collecting tubule. Hence, the number of collecting ducts in the outer medulla is $\mathrm{NL}(0) / 6$. In the inner medulla, collecting ducts merge in a dichotomous mode that results in a treelike structure composed of about $2^{9} \mathrm{CD}(25,27)$. Thus, in the inner medulla the effective total circumference of all CD decreases exponentially from the outer-inner medullary junction to the tip of the papilla. The function $\operatorname{NCD}(x)$ reflects this exponential decrease in the number of $\mathrm{CD}$ in IM. In addition, $\mathrm{NCD}(\mathrm{x})$ takes into account an approximate doubling of the radius of a single CD from outer-inner medullary junction to the papillary tip (25).

\section{Pelvic Reflux}

Recent studies have demonstrated that the epithelium covering the papilla is permeable to urea and possibly to water $(3,48)$. In addition, the composition of the fluid bathing the papilla has been shown to be an important determining factor for inner medullary solute concentration $(4,13,49)$. Therefore, the pelvis was incorporated into the model as a single well-mixed compartment surrounding the papilla (Fig. 3). The model allows for urea reflux across the lateral wall (PRUS) and across the covering wall (PRUC) of the papilla.

\section{RESULTS}

\section{Medullary Longitudinal Solute Gradients}

Figure 4 shows the computed concentrations of salt and urea in stages I-IV of development along the medullary countercurrent system. Each point on these curves represents the computed "slice" concentration. This value is the mean concentration at a given transversal section, that is, including tubule lumens, vasa recta, and interstitium. The term "slice" concentration and its calculation has been extensively described in a previous report (35). Each curve describes the concentration gradient from the corticomedullary (c-m) boundary to the papillary tip for a given stage.

In stage I, salt concentration at the $\mathrm{c}-\mathrm{m}$ border was $139.6 \mathrm{mM}$ and it remained almost constant (141.7) at the outer-inner medullary (OM/IM) transition to the papilla (140.7). In stage II, salt at the c-m border was $136.8 \mathrm{mM}$, 156.6 at $\mathrm{OM} / \mathrm{IM}$, and 152.2 at the papilla. In stage III, salt at the $\mathrm{c}-\mathrm{m}$ border was $129.7 \mathrm{mM}$ and increased greatly to 418.4 at the OM/IM to reach 613.9 at the papilla. In stage IV, the salt concentration changed fur- 


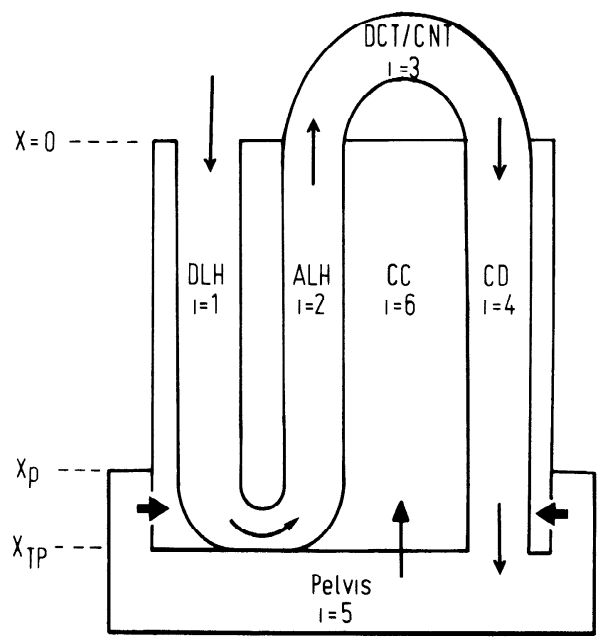

FIG. 3. Scheme of central core model indicating pelvic reflux across lateral wall of the papillary CC (PRUS, $\rightarrow$ ) and across its covering wall (PRUC, $\rightarrow$ ). Adapted from Ref. 35.
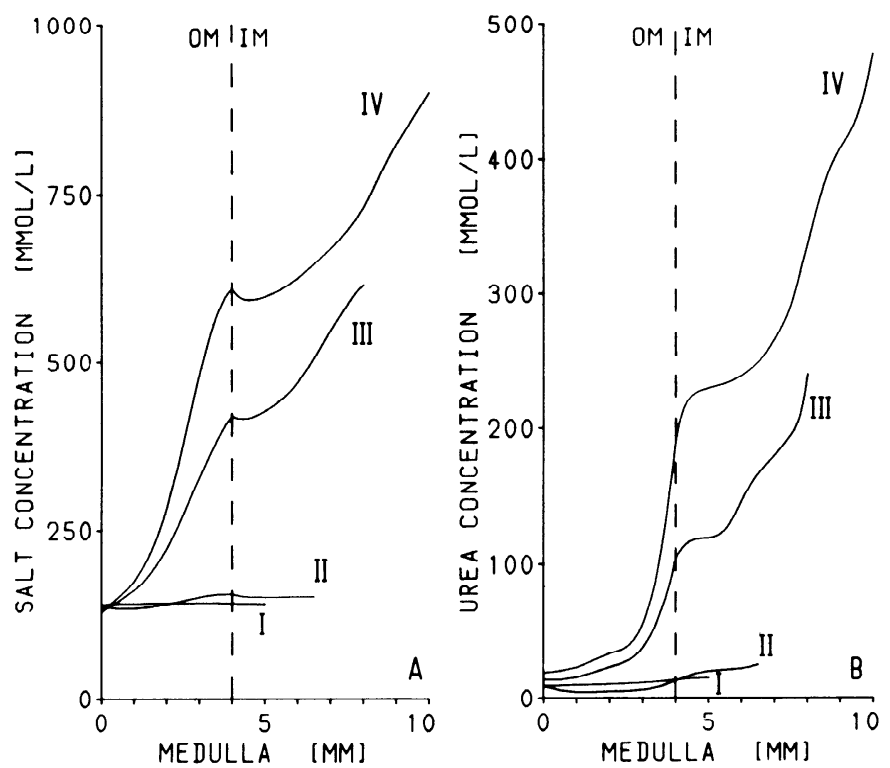

FIG. 4. Computed slice concentrations of salt (left) and urea (right) in stages I-IV along medullary countercurrent system.

ther from $128.5 \mathrm{mM}$ at the entry level to 608.1 at the $\mathrm{OM} / \mathrm{IM}$ transition to 900.4 at the papilla.

Urea concentration in stage I was $9.2 \mathrm{mM}$ at the c-m border and remained in this low concentration range at the OM/IM (13.7) and papillary level (15.2). In stage II, urea concentration at the medullary entry level was 9.4 $\mathrm{mM}, 13.2$ at the OM/IM, and a slight change to only $25.0 \mathrm{mM}$ at the tip of the system was calculated. By contrast, urea concentration in stage III started at 14.0 $\mathrm{mM}$ at the c-m border and it rose to 104.0 and 240.2 at $\mathrm{OM} / \mathrm{IM}$ and papilla, respectively. A further increase in the medullary urea gradient occurred in stage IV where the entry concentration was $18.9 \mathrm{mM}$, the OM/IM urea was 191.9 , and urea at the papillary tip was 478.6.

A similar pattern of solute concentration changes was calculated for loop of Henle concentration (Fig. 5). In stages I and II, salt concentration at OM/IM and papillary tip ranged from 140.2 to $154.9 \mathrm{mM}$; urea concentra- tion, similarly, did not change significantly in DLH and ALH during stages I and II. The principal change of the solute gradient occurred between stage II and III and continued up to stage IV. Salt and urea appeared to increase pari passu,

The same general mode of increase was seen for the concentrations in central core (Fig. 6). By contrast, the outer medullary rise of the $\mathrm{CD}$ salt concentration in stages III and IV was similar, and a further increase was seen in the inner medulla only during stage IV. The values for salt and urea concentration in pelvic urine are listed in Table 6.

To evaluate the role of active salt transport and of medullary geometry separately, two simulation analyses were performed.
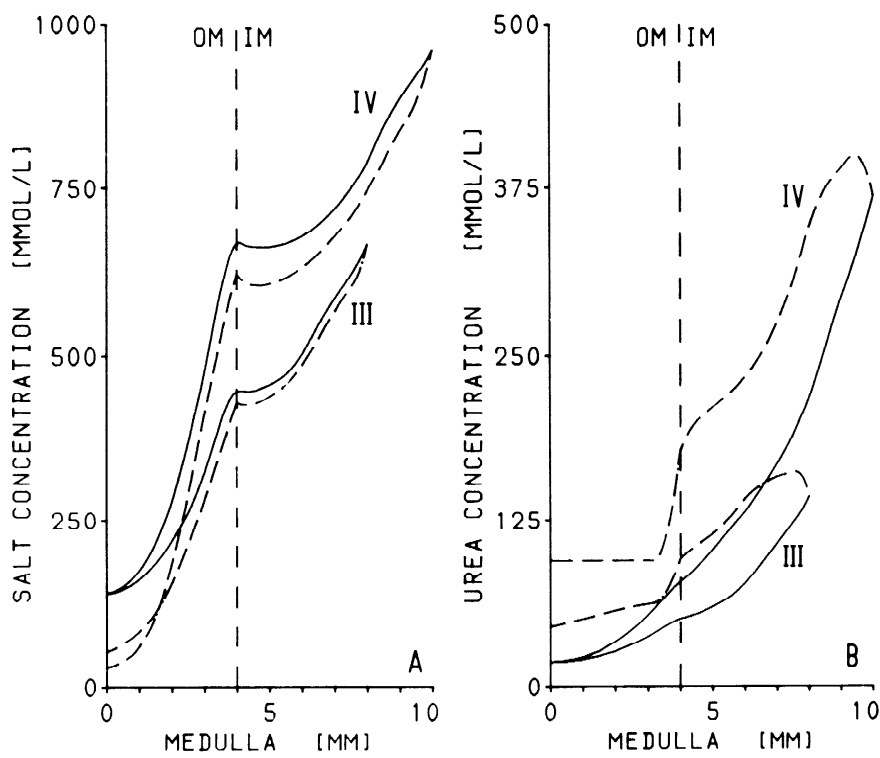

FIG. 5. Concentrations of salt (left) and urea (right) in descending (-) and ascending (---) loop of Henle in stages III and IV.
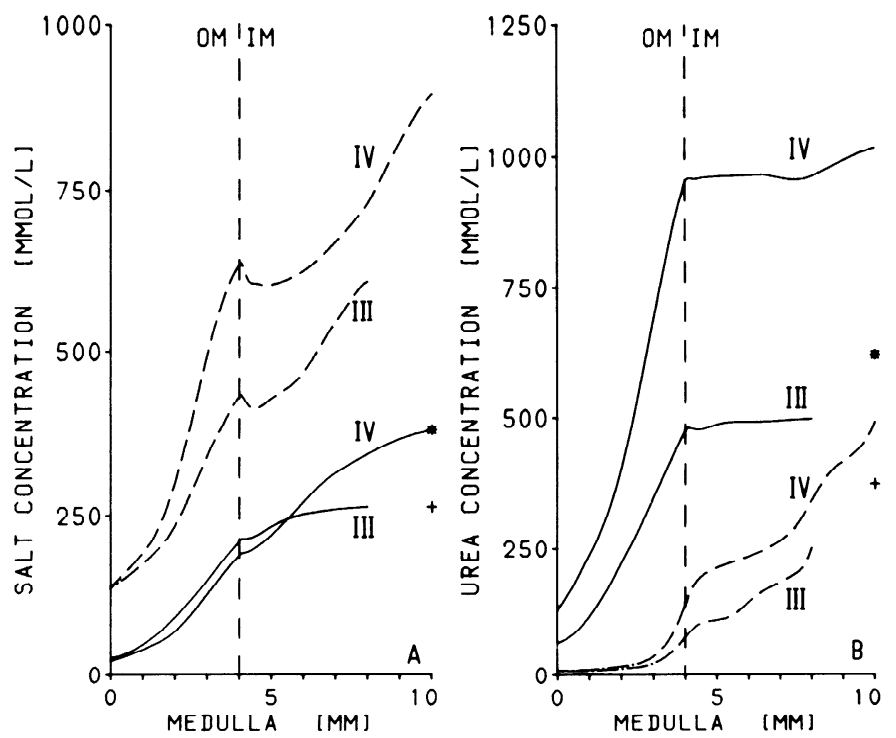

FIG. 6. Concentrations of salt (left) and urea (right) in collecting duct (-) and central core (-.-) in stages III and IV of development. Pelvic concentration in stages III $(+)$ and IV $\left({ }^{*}\right)$ are indicated. 


\section{Changes of Active Salt Transport Rate}

Figure 7 shows the changes of medullary salt and urea gradients in response to a reduction by $13.6 \%$ of the active salt transport rate in the TALH and DCT/CNT, reflecting the values of stage III. The major concentration difference for both salt and urea in this circumstance took place in the outer medullary gradient consequent to the localization of the transport change. The reduction in papillary concentrations was similar for salt and urea. Values were $900.4 \mathrm{mM}$ for salt and $478.6 \mathrm{mM}$ for urea with normal salt transport, and $798.3 \mathrm{mM}$ for salt and $387.4 \mathrm{mM}$ for urea in reduced salt transport.

\section{Role of Medullary Geometry}

The importance of the changing medullary geometry, that is, the changing localization of loops of Henle within the medulla and the increase in length of the medulla, is apparent from Fig. 8. The paired curves represent stage III with its measured normal salt transport and stage IV with an active salt transport reduced to that of stage III. The differences at the OM/IM transition are $95.1 \mathrm{mM}$ for salt and $46.0 \mathrm{mM}$ for urea; at the papillary tip, these values are $184.4 \mathrm{mM}$ for salt and $147.2 \mathrm{mM}$ for urea. It is of interest that the slope of the concentration profile increases toward the papilla, where the final $2 \mathrm{~mm}$ of medullary tissue in stages III and IV are immersed in the

TABLE 6. Developmental changes of pelvic solutes

\begin{tabular}{ccccc}
\hline & \multicolumn{5}{c}{ Stage } \\
\cline { 2 - 5 } & I & II & III & IV \\
\hline C & 134.8 & 129.2 & 262.5 & 380.8 \\
U & 14.7 & 33.5 & 372.6 & 619.7 \\
\hline
\end{tabular}

Salt $(\mathrm{C})$ and urea $(\mathrm{U})$ concentrations $(\mathrm{mM})$ in the renal pelvis.

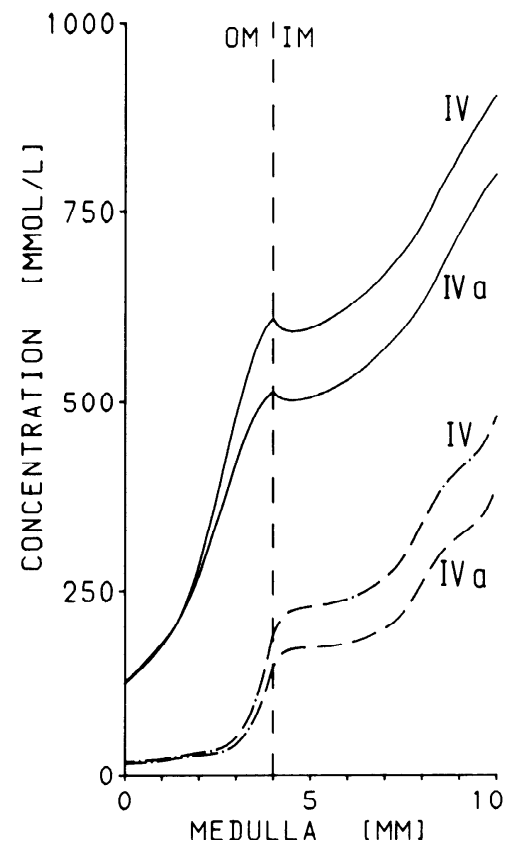

FIG. 7. Computed slice concentrations of salt (-) and urea (-.-) in stage IV at final (IV) and at reduced (IVa) active transport rate of salt.

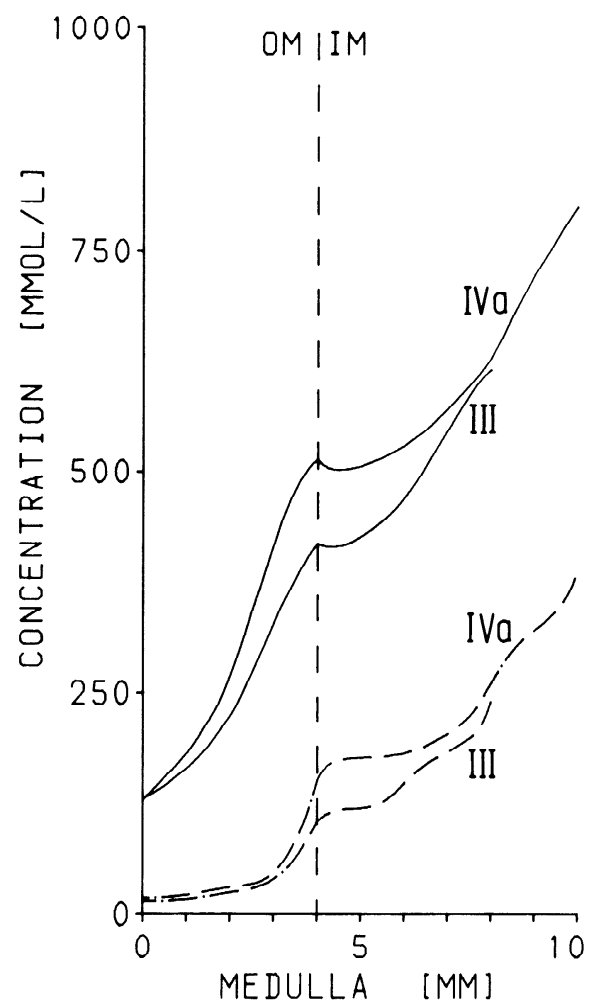

FIG. 8. Computed slice concentrations of salt (-) and urea (-.-) in stage IV at reduced salt transport rate (IVa) and in stage III of ontogeny (III).

pelvic urine and hence reflect the influence of pelvic reflux (35).

\section{DISCUSSION}

\section{Medullary Solute Gradients in Vivo}

Surprisingly few measured data are available on the pattern of longitudinal salt and urea gradients during medullary development (19). In the rabbit, salt concentration in the total outer medulla increases by a factor of about 3 from newborn to adult, while papillary salt and urea concentrations rise by factors of 4-4.5 (11). Comparable data in the rat have not been reported $(9$, 58 ). In the dog kidney, papillary salt and urea concentrations increase by a factor of about 3.5 (16). Therefore, the principal in vivo patterns of medullary and papillary solute gradients with ontogeny have been replicated in the present model simulation. In addition, the attainment of urinary osmotic concentration capacity with stage III of this model concurs with in vivo (rat, rabbit) observations $(9,19,58,59)$.

The major change in the computed medullary solute gradients is apparent between stages II and III (Fig. 4). Neither salt nor urea concentrations along the medullary longitudinal axis change significantly up to stage II. It is of interest that salt and urea do not increase equally between stages II and III; while the papillary salt concentration rises by a factor of 4 , urea increases about 10 fold. This differential change of the principal solutes can be derived from measurements of urea and total solutes in the rat papilla (9). The rate difference calculated in the present model for salt and urea persists during stages 
III-IV in which salt changes by $47 \%$ and urea by $99 \%$. Therefore, the changing contribution of papillary urea to urinary osmotic concentration is more important than that of salt.

This relationship is similar, albeit to a smaller extent, in the outer medulla (OM). The computed salt concentration at the OM/IM border increases by a factor of 2.7 during stages II and III whereas urea changes 7.9 -fold. Subsequent concentration changes at the OM/IM transition during stages III and IV are smaller: 1.45 -fold for salt and 1.85-fold for urea. In particular, these OM/IM changes are very similar to those of the papillary salt and urea. Therefore, the slopes of salt and urea concentrations along the medulla are similar in stages III and IV, suggesting that the final relationship of the mechanisms for solute concentration has been reached in stage III and the further rise to stage IV is merely quantitative.

In the loop of Henle, as illustrated in Fig. 5, the continuous changes of salt and urea concentrations in stages III and IV reveal patterns similar to those of the slice concentrations (Fig. 4).

\section{Evidence for Differential Role of Active Salt Transport and Medullary Geometry}

The effect of a reduction in active salt transport in stage IV on medullary salt and urea gradients is illustrated in Fig. 7. There is a decrease in both salt and urea at the OM/IM border that, however, is already apparent in the inner stripe and persists throughout the inner medulla. Thus, changes in active salt transport of the thick ascending loop do not influence the characteristic but the level of the inner medullary solute gradients.

The role of changing medullary geometry for medullary solute gradients is apparent from Fig. 8. The difference in salt and urea gradients in these circumstances reflects the influence of medullary structural organization on medullary countercurrent function in two developmental stages. The major change appears to be in the inner stripe of the outer medulla for both salt and urea.

In conclusion, this model study on the ontogenetic evolution of urinary osmotic concentration provides evidence for the assumption $(18,37,50)$ that the increasing salt transport capacity of the thick ascending loop in conjunction with the organization of the microarchitecture, and its consequences for solute delivery, quantitatively account for the changing tissue solute accumulation in the renal medulla.

\section{APPENDIX}

For $\mathrm{i}=1,2,4$ (medullary tubules) and $\mathrm{i}=5$ (pelvis) the transmural fluxes are given by

$$
\begin{gathered}
\mathrm{J}_{\mathrm{v}_{\mathrm{t}}}=\mathrm{L}_{\mathrm{p}_{\mathrm{i}}} \times \sum_{\mathrm{j}=1}^{2} n \mathrm{\jmath} \Phi_{\mathrm{j}} \sigma_{\mathrm{ij}} \times\left(\mathrm{C}_{6 \mathrm{j}}-\mathrm{C}_{\mathrm{ij}}\right) \\
\mathrm{S}_{\mathrm{j}}=\mathrm{P}_{\mathrm{j}} \times\left(\mathrm{C}_{\mathrm{j}}-\mathrm{C}_{6 \mathrm{j}}\right)+\left(1-\sigma_{\mathrm{j}}\right) \times \mathrm{J}_{\mathrm{v}_{\mathrm{i}}} \times \overline{\mathrm{C}_{\mathrm{ij}}}+\mathrm{T}_{\mathrm{j}} \quad \mathrm{j}=1,2
\end{gathered}
$$

where $\overline{\mathrm{C}_{\mathrm{j}}}=\left(\mathrm{C}_{\mathrm{y}}+\mathrm{C}_{6 \mathrm{\jmath}}\right) / 2$.

The active transport, $T_{y}$, is assumed to obey Michaelis-Menten kinetics, namely

$$
\mathrm{T}_{\mathrm{u}}=\frac{V_{\mathrm{m}_{\mathrm{y}}} \cdot C_{\mathrm{v}}}{K_{\mathrm{m}_{\mathrm{v}}}+C_{\mathrm{y}}}
$$

During passage through the DCT/CNT, the fluid interacts with the cortical interstitium, where the solute concentrations are assumed to be the same as in arterial plasma. Hence, in this region

$$
\begin{gathered}
\mathrm{J}_{\mathrm{v}_{3}}=\mathrm{L}_{\mathrm{p}_{3}} \times \sum_{\mathrm{j}=1}^{2} n_{\mathrm{j}} \Phi_{\mathrm{j}} \sigma_{3 \mathrm{j}} \times\left(\mathrm{C}_{\mathrm{p}_{\mathrm{j}}}-\mathrm{C}_{3 \mathrm{j}}\right) \\
\mathrm{S}_{\mathrm{3}_{\mathrm{j}}=\mathrm{P}_{3 \mathrm{j}} \times\left(\mathrm{C}_{3 \mathrm{j}}-\mathrm{C}_{\mathrm{p}_{\mathrm{j}}}\right)+\left(1-\sigma_{3 \mathrm{j}}\right)} \\
\times \mathrm{J}_{\mathrm{v}_{3}} \times \overline{\mathrm{C}_{3 \mathrm{j}}}+\mathrm{T}_{3 \mathrm{j}} \quad \mathrm{j}=1,2
\end{gathered}
$$

For the reasons outlined previously (38) it was assumed that in the tubules axial movement of solute is by convection only

$$
\mathrm{F}_{\mathrm{ij}}=\mathrm{F}_{\mathrm{iv}} \times \mathrm{C}_{\mathrm{ij}} \quad \mathrm{i}=1, \ldots, 4, \mathrm{j}=1,2
$$

$\left(\mathscr{F}_{\mathrm{ij}}=\mathscr{F}_{\mathrm{iv}} \times \mathrm{C}_{\mathrm{u}}\right.$, respectively. $)$

However, in the central core, solute movement along the corticomedullary axis can occur by both diffusion and convection.

$$
\mathrm{F}_{6 \mathrm{j}}=\mathrm{F}_{6 \mathrm{v}} \times \mathrm{C}_{6 \mathrm{j}}-D_{\mathrm{j}} \times \mathrm{AC}(x) \times \mathrm{dC}_{6 \mathrm{j}} / \mathrm{d} x \quad \mathrm{j}=1,2
$$

The differential equations for the composite loop of Henle are (35)

$$
\begin{gathered}
\mathrm{dF}_{1 \mathrm{v}} / \mathrm{d} x=-2 \pi r_{1} \times \mathrm{J}_{\mathrm{v}_{1}} \\
\mathrm{dF}_{1 \mathrm{j}} / \mathrm{d} x=-2 \pi r_{1} \times \mathrm{S}_{1 \mathrm{j}} \quad \mathrm{j}=1,2 \\
\mathrm{~d} \mathscr{F}_{2 \mathrm{v}} / \mathrm{d} x=-2 \pi r_{2} \times \mathrm{NL}(x) \times \mathrm{J}_{\mathrm{v}_{2}}-\mathrm{NL}^{\prime}(x) \times \mathrm{F}_{1 \mathrm{v}} \\
\mathrm{d} \mathscr{F}_{2 \mathrm{j}} / \mathrm{d} x=-2 \pi r_{2} \times \mathrm{NL}(x) \times \mathrm{S}_{2 \mathrm{j}}-\mathrm{NL}^{\prime}(x) \times \mathrm{F}_{1_{\mathrm{j}}} \quad \mathrm{j}=1,2
\end{gathered}
$$

In the DCT/CNT, the number of tubules is constantly NL(0). Thus, the differential equations for the composite structure are

$$
\begin{gathered}
\mathrm{d} \mathscr{F}_{3 \mathrm{v}} / \mathrm{d} x=-2 \pi r_{3} \times \mathrm{NL}(0) \times \mathrm{J}_{\mathrm{v} 3} \\
\mathrm{~d} \mathscr{F}_{3 \mathrm{j}} / \mathrm{d} x=-2 \pi r_{3} \times \mathrm{NL}(0) \times \mathrm{S}_{3 \mathrm{j}} \quad \mathrm{j}=1,2
\end{gathered}
$$

The composite CD structure is described by

$$
\begin{gathered}
\mathrm{d} \mathscr{F}_{4 \mathrm{v}} / \mathrm{d} x=-2 \pi r_{4} \times \operatorname{NCD}(x) \times \mathrm{J}_{\mathrm{v}_{4}} \\
\mathrm{~d} \mathscr{F}_{4 \mathrm{j}} / \mathrm{d} x=-2 \pi r_{4} \times \operatorname{NCD}(x) \times \mathrm{S}_{4 \mathrm{j}} \quad \mathrm{j}=1,2
\end{gathered}
$$

The total amount of pelvic urea reflux across the side wall of the papillary $\mathrm{CC}$ is determined by

$$
\text { PRUS }=\int_{x_{\mathrm{P}}}^{x_{\mathrm{TP}}} 2 \pi r_{5}(x) \times \mathrm{S}_{52}(x) \mathrm{d} x
$$

and across the cover wall

$$
\text { PRUC }=\mathrm{AC}\left(x_{\mathrm{TP}}\right) \times \mathrm{P}_{52} \times\left[\mathrm{C}_{52}-\mathrm{C}_{62}\left(x_{\mathrm{TP}}\right)\right]
$$

The differential equations for the tubules and the pelvis are coupled by the differential equations for the central core flows, which are derived from the requirement of mass balance

$$
\begin{gathered}
\mathrm{dF}_{6 \mathrm{v}} / \mathrm{d} x=-\sum_{\substack{l=1 \\
l \neq 3}}^{4} \mathrm{~d}_{\mathrm{F}_{\mathrm{vv}}} / \mathrm{d} x \\
\mathrm{dF} \mathrm{G}_{\mathrm{g}_{3}} / \mathrm{d} x=-\sum_{\substack{i=1 \\
i \neq 3}}^{4} \mathrm{~d} \mathscr{F}_{1 \mathrm{j}} / \mathrm{d} x+2 \pi r_{5}(x) \times \mathrm{S}_{5_{\mathrm{j}}} \\
\mathrm{j}=1,2 \text { where } \mathrm{S}_{51}=0
\end{gathered}
$$

Altogether, equations A1-A17 define an extensive system of 18 simultaneous differential equations of first order. The corresponding boundary conditions for the tubules are

$$
\begin{aligned}
& \mathrm{F}_{1 \mathrm{v}}(0)=\mathrm{Q}_{\mathrm{o}}, \quad \mathrm{F}_{11}(0)=\mathrm{Q}_{\mathrm{o}} \times \mathrm{C}_{\mathrm{p}_{1}}, \quad \mathrm{~F}_{12}(0)=\mathrm{Q}_{\mathrm{o}} \times 2 \mathrm{C}_{\mathrm{p}_{2}} \\
& \mathscr{F}_{2 \mathrm{v}}\left(x_{\mathrm{TP}}\right)=-\mathrm{F}_{1 \mathrm{v}}\left(x_{\mathrm{TP}}\right) \times \mathrm{NL}\left(x_{\mathrm{TP}}\right) \\
& \mathscr{F}_{2 \mathrm{j}}\left(x_{\mathrm{TP}}\right)=-\mathrm{F}_{1 \mathrm{j}}\left(x_{\mathrm{TP}}\right) \times \mathrm{NL}\left(x_{\mathrm{TP}}\right) \quad \mathrm{j}=1,2 \\
& \mathscr{F}_{3 \mathrm{v}}(0)=-\mathscr{F}_{2 \mathrm{v}}(0), \mathscr{F}_{3 \mathrm{j}}(0)=-\mathscr{F}_{2 \mathrm{j}}(0) \quad \mathrm{j}=1,2 \\
& \mathscr{F}_{4 \mathrm{v}}(0)=\mathscr{F}_{3 \mathrm{v}}\left(\mathrm{L}_{\mathrm{DCT}}+\mathrm{L}_{\mathrm{CNT}}\right)+\mathrm{NCN} \times \mathrm{Q}_{\mathrm{CN}} \\
& \mathscr{F}_{4 \mathrm{j}}(0)=\mathscr{F}_{3 \mathrm{j}}\left(\mathrm{L}_{\mathrm{DCT}}+\mathrm{L}_{\mathrm{CNT}}\right)+\mathrm{NCN} \times \mathrm{Q}_{\mathrm{CN}} \times \mathrm{C}_{\mathrm{pj}} \quad \mathrm{j}=1,2
\end{aligned}
$$


The boundary conditions for the central core are

$$
\begin{gathered}
\mathrm{C}_{6 \mathrm{j}}(0)=\mathrm{C}_{\mathrm{p}_{3}} \quad \mathrm{j}=1,2 \\
\mathrm{~F}_{6 \mathrm{vv}}\left(x_{\mathrm{TP}}\right)=0, \quad \mathrm{~F}_{61}\left(x_{\mathrm{TP}}\right)=0, \quad \mathrm{~F}_{62}\left(x_{\mathrm{TP}}\right)=-\mathrm{PRUC}
\end{gathered}
$$

The boundary conditions for the pelvis result from the requirement of mass balance

$$
\mathscr{F}_{4 \mathrm{v}}\left(x_{\mathrm{TP}}\right) \times \mathrm{C}_{52}=\mathscr{F}_{42}\left(x_{\mathrm{TP}}\right)-\text { PRUS - PRUC }
$$

The boundary value problem, equations A1-A24, was solved numerically by multiple shooting $(5,56)$. The code includes a relaxation technique for the damped Newton method (8). The linear equations for the Newton corrections were solved in a direct manner (35a, 39). The initial value problems (56) were solved by a Runge-Kutta-Fehlberg method of seventh order (10) with an automatic control of the integration step sizes according to a prescribed tolerance. These techniques guarantee precise and reliable results, as pointed out for kidney models

\section{REFERENCES}

1. Al-Zahid, G., J. A. Schafer, S. L. Troutman, and T. E. ANDREOLI. The effect of antidiuretic hormone in water and salt permeation, and the activation energies for these processes, in mammalian cortical collecting tubules. Evidence for parallel $\mathrm{ADH}$ sensitive pathways for water and solute diffusion in luminal plasma membranes. J. Membr. Biol. 31: 103-129, 1977.

2. APERIA, A., AND G. Elinder. Distal tubular sodium reabsorption in the developing rat kidney. Am. J. Physiol. 240 (Renal Fluid Electrolyte Physiol. 9): F487-F491, 1981.

3. Bonventre, J. V., M. J. Karnovsky, AND C. P. LeChene. Renal papillary epithelial morphology in antidiuresis and water diuresis. Am. J. Physiol. 235 (Renal Fluid Electrolyte Physiol. 4): F69-F76, 1978.

4. Bonventre, J. V., AND C. LEChene. Effect of urea concentration of pelvic fluid on renal concentration ability. Am. J. Physiol. 239 (Renal Fluid Electrolyte Physiol. 8): F609-F618, 1980.

5. Bulirsch, R. Die Mehrzielmethode zur numerischen Losung von nichtlinearen Randwertproblemen und Aufgaben der optimalen Steuerung. Report of the Carl-Cranz-Gesellschaft, Heidelberg, 1971.

6. BURG, M., AND N. GREen. Function of the thick ascending limb of Henle's loop. Am. J. Physiol. 224: 658-659, 1973.

7. CAPEK, K., G. Fuda, G. Rumrich, and K. J. Ullrich. Harnstoffpermeabilität der corticalen Tubulusabschnitte von Ratten in Antidiurese und Wasserdiurese. Pfluegers Arch. 290: 237-249, 1966.

8. Deuflhard, P. A relaxation strategy for the modified Newton method. In: Optimization and Optimal Control, edited by R. Bulirsch, W. Oettli, and J. Stoer. Berlin: Springer-Verlag, 1975, p. $59-73$.

9. Edwards, B. R., D. Mendel, R. LaRochelle, P. Stern, and H. VALTIN. Postnatal development of urinary concentrating ability in rats: changes in renal anatomy and neurohypophysial hormones. In: The Kidney during Development. New York: Masson, 1982, p. 233-239.

10. Fehlberg, E. Klassische Runge-Kutta-Formeln fünfter und siebenter Ordnung mit Schrittweitenkontrolle. Computing 4: 93-106, 1969.

11. Fleischaker, G. H., O. J. Gesink, and W. W. McCrory. Effect of age on distribution of urea and electrolyte in kidneys of young rabbits (Abstract). Am. J. Dis. Child. 100: 557, 1960.

12. Foster, D. M., AND J. A. JACQUEz. Comparison using central core model of renal medulla of the rabbit and the rat. Am. J. Physiol. 234 (Renal Fluid Electrolyte Physiol. 3): F402-F414, 1978.

13. Gertz, K. H., B. SchmidT-NiElsen, AND H. D. PAGel. Exchange of water, urea and salt between the mammalian renal papilla and the surrounding urine (Abstract). Federation Proc. 25: 327, 1966.

14. Goncharevskaya, O. A., AND H. Dlouha. The development of various generations of nephrons during postnatal ontogenesis in the rat. Anat. Rec. 182: 367-376, 1975.

15. Henle, J. Handbuch der Systematischen Anatomie des Menschen Eingeweidelehre, Braunschweig: Vieweg, 1866, p. 299-310.

16. Horster, M. Principles of nephron differentiation. Am. J. Physiol. 235 (Renal Fluid Electrolyte Physiol. 4): F387-F394, 1978.

17. Horster, M. Loop of Henle functional differentiation. In vitro perfusion of the isolated thick ascending segment. Pfluegers Arch.
(34). An important check is the overall conservation of mass in the entire medulla. In the results of the present study, mass inflow agreed with mass outflow to a relative accuracy of at least $4.10^{-7}$ for both water and the solutes. The computations were performed on the CDC Cyber 175 (48-bit mantissa) of the Leibniz-Rechenzentrum der Bayerischen Akademie der Wissenschaften.

Work in the laboratory of M. Horster is supported by the Deutsche Forschungsgemeinschaft.

Part of this study has been reported in abstract form (Pfluegers Arch. 391: R16, 1981).

Send reprint requests to Michael F. Horster, Physiologisches Institut, Universitat Müchen, Pettenkoferstrasse 12, D-8000 Müchen 2, FRG.

Received 28 March 1983; accepted in final form 23 August 1983.

378: 15-24, 1978.

18. HORSTER, M. Expression of ontogeny in individual nephron segments. Kidney Int. 22: 550-559, 1982.

19. Horster, M. Ontogenetic processes in nephron epithelia. Function, enzymes and structure. In: Physiology and Pathology of Electrolyte Metabolism, edited by D. Seldin and G. Giebisch. New York: Raven, 1984.

20. HORSTER, M., AND L. LARSSON. Mechanisms of fluid absorption during proximal tubule development. Kidney Int. 10: 348-363, 1976.

21. Honster, M., aND H. Valtin. Postnatal development of renal function: micropuncture and clearance studies in the dog. J. Clin. Invest. 50: 779-795, 1971.

22. Horster, M. F., AND H. ZINk. Functional differentiation of the medullary collecting tubule: influence of vasopressin. Kidney Int. 22: 360-365, 1982.

23. ImaI, M., AND J. P. KoкKo. Sodium chloride, urea and water transport in the thin ascending limb of Henle: generation of osmotic gradients by passive diffusion of solutes. J. Clin. Invest. 53: 393-402, 1974.

24. JACQUEZ, J. A., D. Foster, AND E. DANIELs. Solute concentration in the kidney-I. A model of the renal medulla and its limit cases. Math. Biosci. 32: 307-335, 1976.

25. KAINER, R. A geometric model of the rat kidney. Anat. Embryol. 147: 91-109, 1975.

26. KAISSLING, B. Ultrastructural characterization of the connecting tubule and the different segments of the collecting duct system in the rabbit kidney. In: Biochemical Nephrology, edited by W. Guder and U. Schmidt. Bern: Huber, 1978, p. 99-119.

27. KaISSLING, B., AND W. KRIZ. Structural analysis of the rabbit kidney. Adv. Anat. Embryol. Cell Biol. 56: 1-121, 1979.

27a.KNePper, M. A., R. A. Danielson, G. M. SAIDEL, AND R. S. Post. Quantitative analysis of renal medullary anatomy in rats and rabbits. Kidney Int. 12: 313-323, 1977.

28. KокKо, J. P. Sodium chloride and water transport in the descending limb of Henle. J. Clin. Invest. 49: 1838-1846, 1970.

29. KокKо, J. P. Urea transport in the proximal tubule and the descending limb of Henle. J. Clin. Invest. 51: 1999-2008, 1972.

30. Кокко, J. P., AND F. C. Rector, JR. Countercurrent multiplication system without active transport in inner medulla. Kidney Int. 2: $214-233,1972$.

31. KRIZ, W. Der architektonische und funktionelle Aufbau der Rattenniere. Z. Zellforsch. Mikrosk. Anat. 82: 495-535, 1967.

32. KRIZ, W. Structural organization of the renal medulla: comparative and functional aspects. Am. J. Physiol. 241 (Regulatory Integrative Comp. Physiol. 10): R3-R16, 1981.

33. Lassiter, W. E., A. Frick, G. RUMrich, and K. J. UllRich. Influence of ionic calcium on the water permeability of proximal and distal tubules in the rat kidney. Pfluegers Arch. 285: 90-95, 1965.

34. LORY, P. Numerical solution of a kidney model by multiple shooting. Math. Biosci. 50: 117-128, 1980.

35. LORY, P., A. GILG, AND M. HoRSTER. Renal countercurrent system: role of collecting duct convergence and pelvic urea predicted from a mathematical model. J. Math. Biol. 16: 281-304, 1983.

35a.MAIER, M. Numerische Losung singular gestorter Randwertprob- 
leme mit Anwendung auf Halbleitermodelle ( $\mathrm{PhD}$ Dissertation). Munchen: 'T'echnische Universitat München, 1982.

36. MARSH, D. J. Solute and water flows in thin limbs of Henle's loop in the hamster kidney. Am. J. Physiol. 218: 824-831, 1970.

37. MCCANCE, R. A. Renal physiology in infancy. Am. J. Med. 9: 229$441,1950$.

37a.MeJiA, R., AND J. L. STEPhENSON. Numerical solution of multinephron kidney equations. J. Comp. Physiol. 32: 235-244, 1979.

38. Moore, L. C., AND D. J. Marsh. How descending limb of Henle's loop permeability affects hypertonic urine formation. Am. J. Physiol. 239 (Renal Fluid Electrolyte Physiol. 8): F57-F71, 1980.

39. OBERLE, H. J. Numerische Berechnung optimaler Steuerungen von Heizung und Kuhlung fur ein realistisches Sonnenhausmodell. $\mathrm{Ha}$ bilitationsschrift. Munchen: Technische Universitat, 1982.

40. Oliver, J. Nephrons and Kidneys. New York: Harper \& Row, 1968.

41. Osathanondh, V., AND E. L. PotTer. Development of human kidney as shown by microdissection. III. Formation and interrelationship of collecting tubules and nephrons. Arch. Pathol. 76: 290302, 1963.

42. PETER, K. Die Entwicklung der menschlichen Niere nach Isolationspraparaten. In: Untersuchungen uber Bau und Entwicklung der Niere. Jena: Fischer, 1927, p. 517-564.

43. Ricciarelli, G. Morphologische Untersuchungen zur postnatalen Entwicklung der Rattenniere (MD Dissertation). Munster: Univ. of Munster, 1970.

44. RochA, A., AND J. P. KoкKo. Sodium chloride and water transport in the medullary thick ascending limb of Henle. J. Clin. Invest. 52: 612-623, 1973.

45. Rосна, A. S., AND J. P. Koкko. Permeability of medullary nephron segments to urea and water: effect of vasopressin. Kidney Int. 6: 379-387, 1974.

46. SAKaI, F., AND H. Endou. Postnatal development of urea concentration in the newborn rabbit's kidney. Jpn. J. Pharmacol. 21: 677$679,1971$.

47. SchafER, J. A., AND T. E. ANDrEoli. The effect of antidiuretic hormone on solute flows in mammalian collecting tubules. J. Clin. Invest. 51: 1279-1286, 1972.
48. Schmidt-Nielsen, B., M. Churchill, and L. N. Reinking. Occurrence of renal pelvic refluxes during rising urine flow rate in rats and hamsters. Kidney Int. 18: 419-431, 1980.

49. Schutz, W., AND J. SchnermanN. Pelvic urine composition as a determinant of inner medullary solute concentration and urine osmolarity. Pfluegers Arch. 334: 154-166, 1972.

50. Sмiтh, H. W. Renal function in infancy and childhood. In: The Kidney: Structure and Function in Health and Disease. New York: Oxford Univ. Press, 1950, p. 492-519.

51. SPELlER, A. M., AND D. B. MofFAT. Tubulo-vascular relationships in the developing kidney. J. Anat. 123: 487-500, 1977.

52. SPERBER, I. Studies on the mammalian kidney. Zool. Bidr. Uppsala 22: $249-431,1944$.

53. Stanier, M. W. Development of intra-renal solute gradients in foetal and postnatal life. Pfluegers Arch. 336: 263-270, 1972.

54. Stephenson, J. L. Concentration of urine in a central core model of the renal counterflow system. Kidney Int. 2: 85-94, 1972.

55. Stephenson, J. L., R. Mejia, and R. P. Tewarson. Model of solute and water movement in the kidney. Proc. Natl. Acad. Sci. USA 73: 252-256, 1976.

55a.Stephenson, J. L., R. P. Tewarson, and R. Mf.JIA. Quantitative analysis of mass and energy balance in nonideal models of the renal counterflow system. Proc. Natl. Acad. Sci. USA 71: 1618$1622,1974$.

56. Stoer, J., AND R. Bulirsch. Introduction to Numerical Analysis. New York: Springer, 1980.

57. Ullrich, K. J., G. RumRich, and C. A. Baldamus. Mode of urea transport across the mammalian nephron. In: Urea and the Kidney, edited by B. Schmidt-Nielsen and D. W. S. Kerr. Amsterdam: Excerpta Medica, 1970, p. 175-185.

58. Yunibhaud, P., and U. HELd. Nierenmark und Urinosmolität nach der Geburt bei der Ratte unter Flussigkeitsentzug. Helv. Physiol. Pharmacol. Acta 23: 91-96, 1965.

59. ZINK, H., AND M. HoRstFr. Maturation of diluting capacity in loop of Henle of rat superficial nephrons. Am. J. Physiol. 233 (Renal Fluid Electrolyte Physiol. 2): F519-F524, 1977. 